\title{
Extraction of Cadmium from Aqueous Solutions by Emulsion Liquid Membranes using a Stirred Transfer Cell Contactor
}

\author{
Carlos Basualto, ${ }^{* a}$ Maritza Poblete, ${ }^{a}$ José Marchese, ${ }^{b}$ Ariel Ochoa, ${ }^{b}$ Adolfo Acosta, ${ }^{b}$ Jaime Sapag ${ }^{a}$ \\ and Fernando Valenzuela*,a \\ ${ }^{a}$ Laboratorio de Operaciones Unitarias, Facultad de Ciencias Químicas y Farmacéuticas, Universidad de Chile, \\ Casilla 233, Vicuña Mackenna 20, Santiago, Chile \\ ${ }^{b}$ Laboratorio de Ciencias de Superficies y Medios Porosos, Departaento de Química, Universidad Nacional de San \\ Luis, Chacabuco 917, San Luis, Argentina
}

\begin{abstract}
Foi estudada a extração de íons cádmio(II) a partir de soluções aquosas ácidas, usando, em uma cela de transferência sob agitação, uma membrana líquida em emulsão, (MLE) preparada pela mistura de querosene com D2EHPA (um ácido alquilfosfórico) como carregador móvel e Span-80 como surfactante. A membrana MLE permitiu transporte eficiente do metal, da solução de alimentação para o extrato de coleta em experimentos realizados a $25{ }^{\circ} \mathrm{C}$. As variáveis significativas no transporte de cádmio através da membrana foram a concentração do extrator e a quantidade de metal na solução alimentadora. A concentração de $\mathrm{HCl}$ como agente de coleta afetou somente a taxa inicial de extração do metal, mas não a extensão da extração. A quantidade de surfactante usada neste estudo estabilizou a membrana adequadamente, mas o uso de uma quantidade maior produziu uma menor taxa de extração inicial devido à resistência inferfacial mais alta. Os resultados experimentais sugerem a possibilidade de recuperação ou remoção de metais tóxicos de soluções aquosas diluídas em um extrator baseado em membranas líquidas emulsificadas.
\end{abstract}

It is studied the extraction of cadmium(II) ions from acidic aqueous solutions using a stirred transfer cell-type emulsion liquid membrane (ELM) prepared by dissolving in kerosene, with D2EHPA (an alkylphosphoric acid) as mobile carrier and Span-80 as surfactant. The ELM allowed efficient metal transport from the feed solution to the stripping liquor in experiments carried out at $25^{\circ} \mathrm{C}$. The significant variables on cadmium transport through the membrane were extractant concentration and metal content in the feed metal-donor solution. Concentration of $\mathrm{HCl}$ as stripping agent affected only the initial metal extraction rate but not the extraction extent. The surfactant content used in this study stabilized the membrane adequately, but the use of a higher content produced a smaller initial extraction rate due to higher interfacial resistance. The experimental results suggest the possibility of recovering or removing valuable or toxic metals from dilute aqueous solution in an extractor based on emulsified liquid membranes.

Keywords: cadmium, liquid membrane, emulsion, extraction

\section{Introduction}

The presence of cadmium ions in many industrial aqueous waste solutions is a complex example of pollution because of its high toxicity, which affects aquatic life and, in extreme cases, human life. Most of these residual waters are acidic, however in some chemical manufacturing processes it is not rare to find aqueous solutions whose

*e-mail: cbasualt@uchile.cl; fvalenzu@uchile.cl
$\mathrm{pH}$ varies even in a range between 7 and 10, with the possible existence of many dissolved heavy metals. However, metals like cadmium have an intrinsic value that justifies their recovery. Cadmium and its compounds, basically alloys, find many applications such as in the chemical and electronic industries. It is common to find cadmium ions in waste waters from industries that work with metal alloys, ceramic materials, electrowinning processes, electronics, pigments, and textiles, and in acid mine drainages, residual waters from leaching and 
flotation steps in copper and other transition metal mines, among others. ${ }^{1}$ These waste waters are therefore potential sources of this metal, which is normally used in a high purity state that requires the use of highly selective methods. Normally available technologies are not a solution because they are expensive and not too effective, and usually the metal concentration in these waste solutions is low, making its recovery uneconomical.

Among the technical alternatives for removing cadmium from aqueous solutions, chemical precipitation as the hydroxide in an alkaline medium can be mentioned, but such precipitates are not always stable, and their redissolving occurs easily and large amounts of sludge accumulate. Another option is the use of solid ionexchange resins, but the method is complex and has problems due to the need to regenerate the loaded resins after adsorption of metals, which is not always quantitative and is also strongly affected by the presence of fine suspended solids, making its use inefficient. ${ }^{2,3}$

Another alternative is the use of solvent extraction processes with organic liquid extractants in mixer-settlertype reactors (SX). This technology has been widely used for the recovery and/or removal of heavy metals in hydrometallurgy. It is an attractive technique for separating and enriching metallic ions from dilute solutions based on the right choice of a highly selective extractant molecule for the desired metal. Yet it presents many difficulties, such as the requirement of a huge inventory of expensive extractant, large plant size to obtain the desired separation, operational difficulties like solvent loss due to crud formation or the entrainment of the organic phase into the aqueous solution, or by volatilization of diluent and degradation of the organic extractants. ${ }^{4}$

Membrane-based solvent extraction processes have been shown to be an effective alternative to the metal removal techniques mentioned above, including solid-supported liquid membranes ${ }^{5-8}$ and surfactant liquid membranes. ${ }^{9,10}$ Particularly, a surfactant liquid membrane process has sufficient ability to selectively separate metals from aqueous solutions using a double W/O/W emulsion stabilized by the use of suitable surfactants, with a reduced amount of organic solvent and greater extraction. The study by Li and co-workers ${ }^{10,11}$ was the first on the industrial applications of emulsion liquid membranes (ELM) and they are normally credited with this invention. Many investigators have studied the practical operation of ELM and the mechanisms that regulate the transport of metals through them, a process that would be regulated by a diffusive phenomenon of mass transfer with a chemical reaction. The ELM method would have the ability to remove and concentrate selectively or collectively, depending on the extractants chosen, the low metal contents present in these residual aqueous solutions, in a continuous and fast process, using a thin liquid membrane that has a large interfacial area and needs only a very small volume of organic solvent. ${ }^{12-20}$ However, it is absolutely necessary to carry out a basic study of its functioning, including the influence of the chemical and hydrodynamic variables that affect the transport and extent of metal extraction. With that purpose, in this study a stirred transfer cell was used which allows determination of the interfacial area and reduces drastically some operational problems such as emulsion breakdown and swelling. The ELM process uses the same extractants used in the SX process, in this case also playing the role of metal carrier from the feed solutions on one side of the membrane to the other side made by the acceptor strip liquor. In this study, a non-specific alkylphosphoric acid compound (di-2ethylhexyl phosphoric acid, D2EHPA) dissolved in kerosene was used as extractant. At first a profile of cadmium species over a wide $\mathrm{pH}$ range, the effect of extractant on the organic/ aqueous interface, and the optimum equilibrium conditions to extract the metal were studied. Special care was taken with the influence of chloride-ion concentration in the aqueous phase feed on the extraction equilibrium and on the initial metal extraction rate in the stirred transfer cell.

\section{Experimental}

\section{Materials}

D2EHPA (di-2-ethylhexyl-phosphoric acid, $\mathrm{C}_{16} \mathrm{H}_{35} \mathrm{PO}_{4}$ ), a widely used nonspecific compound was employed as carrier extractant for cadmium. The phosphoric extractant is a light-yellowish transparent liquid with a molar mass of $322.4 \mathrm{~g} \mathrm{~mol}^{-1}$ and a specific gravity of 0.96 at $20{ }^{\circ} \mathrm{C}$, which was purchased from Sigma. Span-80 (sorbitan monooleate), a well-known nonionic commercial surfactant whose structure has been described, ${ }^{21}$ was used to stabilize the membrane. These compounds were used without further purification and were dissolved in industrial-grade aviation kerosene from Esso-Chile whose composition averages $81 \%$ of aliphatic compounds. This diluent has low volatility and viscosity, making it suitable as solvent because it avoids loss by evaporation at the high stirring speeds needed to form the emulsion system.

The aqueous solutions for $\mathrm{Cd}$ extraction were prepared by dissolving $\mathrm{CdCl}_{2} \cdot 2.5 \mathrm{H}_{2} \mathrm{O}$ in distilled water. The $\mathrm{pH}$ value in the studied range was adjusted with hydrochloric acid, sodium hydroxide and a $0.0125 \mathrm{~mol} \mathrm{~L}^{-1}$ acetic acid/sodium acetate buffer solutions. The initial $\mathrm{Cd}(\mathrm{II})$ content in the feed solution varied between $1 \times 10^{-3}$ and $1 \times 10^{-1} \mathrm{~mol} \mathrm{~L}^{-1}$. 
Concentrated hydrochloric acid solutions were used as stripping agents. In the metal transport experiments carried out in the ELM, this phase constitutes the internal aqueous phase, which acts as a metal acceptor solution. All the other reagents employed were of analytical reagent grade.

\section{Procedure}

First, cadmium liquid-liquid extraction and equilibrium measurements were carried out by contacting in a PolyScience orbital shaker at $25^{\circ} \mathrm{C}$ equal volumes $(20 \mathrm{~mL})$ of aqueous and organic solutions during $3 \mathrm{~h}$, a time in excess sufficient to allow equilibrium to be reached.

All ELM transport experiments in the stirred cell were also carried out at $25{ }^{\circ} \mathrm{C}$. The membrane contactor consisted of a stirred transfer cell with two compartments, the bottom one for the external aqueous solution constituted by the metal aqueous solution, over which a volume of the primary emulsion phase was added carefully, taking care not to disturb the interface. The transfer cell had two turbine-blade stirrers turning in opposite directions. The cadmium-containing aqueous feed phase zone volume was $170 \mathrm{~mL}$, the compartment for the primary emulsion had a volume of $50 \mathrm{~mL}$, and the interfacial area was $27.34 \mathrm{~cm}^{2}$. Both phases, previously conditioned, were stirred gently in their compartments in opposite directions at constant speed with an IkaRuhrwerke RW20 stirrer, keeping a neat interface throughout the experiment.

Previously the primary emulsion was prepared by stirring vigorously the internal aqueous stripping solution with the organic phase consisting of the corresponding extractant and the surfactant dissolved in kerosene, following the experimental procedure previously described in detail..$^{22}$ The stirring was done with an OMNI ultrasonic agitator, which allowed dispersion of the internal aqueous solution in the organic phase, producing an emulsion with small droplets between 0.5 and $100 \mu \mathrm{m}$.

Cadmium content in both the equilibrium and transport experiments was measured by atomic absorption spectrophotometry on a Perkin Elmer Model 3110 apparatus using an air-acetylene flame at a wavelength of $228.8 \mathrm{~nm}$.

\section{Results and Discussion}

\section{Extraction equilibrium}

A number of extractants appropriate for recovery or removal of cadmium from aqueous solutions have been tested, among them amines, preferably tertiary amines, with the metal extracted from an acid phase together with chloride ion..$^{23}$ This type of extractant requires the metal to be preferably in the form of an anionic species with halide ion, like $\mathrm{CdCl}_{3}{ }^{-}$or $\mathrm{CdCl}_{4}{ }_{4}^{2-}$. Quaternary ammonium salts have also been used as efficient cadmium extractants in different diluents according to a chemical mechanism similar to that of amines, i.e. by anion exchange and formation of ion pairs. ${ }^{24}$ However, the metal is not always found in industrial waste solutions with high chloride ion concentrations. Usually, cadmiumcontaining residual aqueous solution have an acid $\mathrm{pH}$ varying within a range of 1-5 and rather low halide ion content. In that case, acidic extractants and even chelating compounds should be used although they require lower acidity to give efficient extraction perfomance. ${ }^{25,26}$ However, metal uptake under these experimental conditions requires the metal to be in the form of the free $\mathrm{Cd}^{2+}$ cationic species which is extractable by the acidic cation-exchange extractant. Figure 1 shows a profile of cadmium species abundance as a function of $\mathrm{pH}$ and chloride ion content in an aqueous metalcontaining solution obtained from the known equilibrium and solubility product constants.

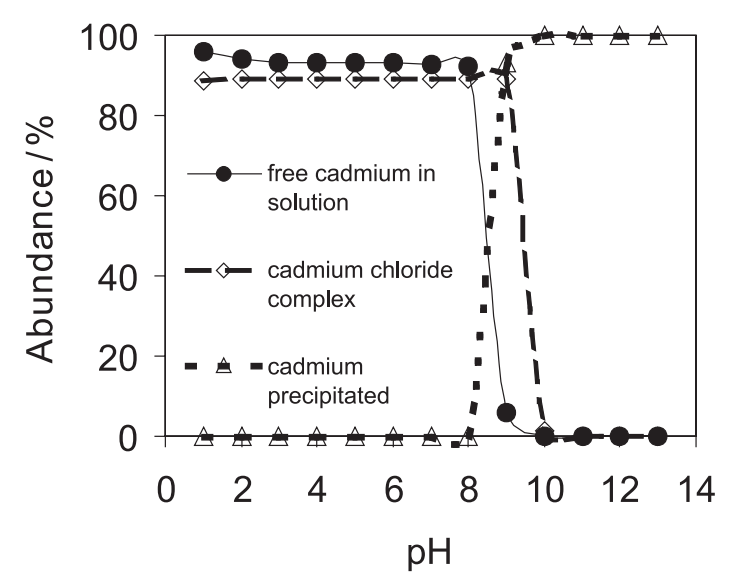

Figure 1. Profile of cadmium species abundance as a function of $\mathrm{pH}$.

It is seen that free $\mathrm{Cd}(\mathrm{II})$ ion species predominate along the acid $\mathrm{pH}$ range and at low chloride ion concentration $\left(10^{-3} \mathrm{~mol} \mathrm{~L}^{-1}\right)$, but at approximately $\mathrm{pH} 7.5$ and above the metal starts precipitating almost quantitatively. However, even in the acidic $\mathrm{pH}$ zone, if halide ion concentration is high, most of the metal appears forming the complex species $\mathrm{CdCl}_{4}{ }^{2-}$, making compulsory under these conditions the use of basic substances as amine-extractants which act by ion-pair formation, whereby a large and positively charged organic species produces the extraction of a large anionic metal complex to the organic phase.

Many authors have pointed out the importance of the nature of the diluent for cadmium extractants, which would 
affect among other things the extraction efficiency and gives rise to some difficulties in aqueous-organic phase separation. Among these studies is possible to stand out the contributions of Stenstrom and Aly ${ }^{27}$ and Alguacil and co-workers. ${ }^{28,29}$ In this study industrial aviation kerosene was used as diluent because it has low volatility suitable for experiments carried out under severe stirring conditions like those produced when a high-shear ultrasonic agitator is used. Therefore, it was important to verify the behavior of the phosphoric extractant dissolved in this diluent toward aqueous solutions. Some equilibrium experiments were carried out contacting the organic solvents with aqueous solutions without metal over a wide $\mathrm{pH}$ range. The change in the initial $\mathrm{pH}$ of the aqueous phase was measured once equilibrium was attained. Figure 2 shows that the acid extractant changed its initial $\mathrm{pH}$. The behavior of the acidic alkylphosphoric compound chosen for the cadmium transport experiments could be accounted for by the fact that this extractant presents some interfacial activity. When placed at the aqueous-organic interface it would undergo a partition and a dissociation process, releasing hydrogen ions to the aqueous phase. This fact causes the reduction of its equilibrium $\mathrm{pH}$ following a typical sinusoidal curve in which the flat middle zone represents the $\mathrm{pH}$ close to its $\mathrm{pKa}$ value, in this case around 2.5 , somewhat higher than reported in the literature.

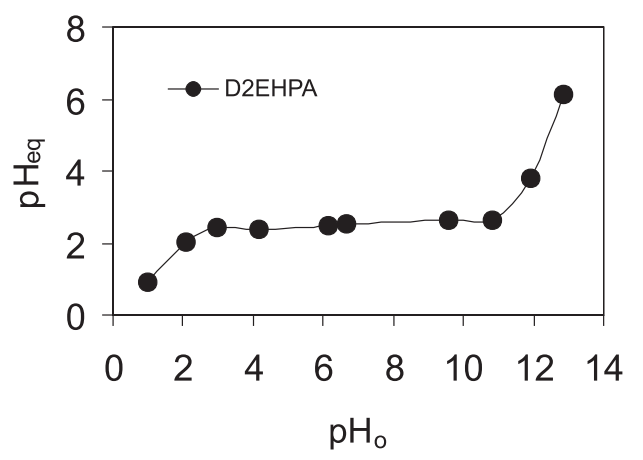

Figure 2. Initial $\mathrm{pH} v s$. equilibrium $\mathrm{pH}$.

It is clear that although the extractant is a weak acid, at the interface it would tend to ionize, increasing the chemical activity of the hydrogen ions through its interfacial activity, finally reacting with the metal by an ion-exchange mechanism based on a heterogeneous interfacial reaction..$^{30}$ Any change of the $\mathrm{pH}$ of the aqueous feed phase would be produced not only by the extraction interfacial chemical reaction but also by the acid character of the extractant.

The metal salt used in this study ionizes in the aqueous phase to form the metal ions $\mathrm{Cd}^{2+}$ which react with the deprotonated extractant species to form the $\mathrm{CdX}_{2}$ species at the aqueous-organic interface. It is well-known that alkylphosphoric extractants are found dimerized in aliphatic diluents like kerosene. ${ }^{31}$ Depending on the metal concentration in the aqueous phase, the reaction's extraction stoichiometry varies and so does the structure of the extracted complex. Assuming that all acid extractant molecules are dimerized in kerosene, the extraction reaction of divalent metals with D2EHPA would proceed in all cases as follows:

$\mathrm{M}^{2+}{ }_{\mathrm{aq}}+\mathrm{n}(\mathrm{HX})_{2 \text { org }}=\mathrm{MX}_{2}(\mathrm{HX})_{2 \mathrm{n}-2 \text { org }}+2 \mathrm{H}^{+}{ }_{\text {aq }}$

At low metal content in aqueous solution, the most probable structure of the extracted complex would be $\mathrm{CdX}_{2}(\mathrm{HX})_{2}$, as has been reported for the extraction of other metals with D2EHPA. ${ }^{32}$ The structure of the complex is shown at the Graphical Abstract (GA) of this paper.

Then the extraction of $\mathrm{Cd}^{2+}$ with the phosphoric compound can be written as follows:

$\mathrm{Cd}^{2+}{ }_{\mathrm{aq}}+2(\mathrm{HX})_{2 \text { org }}=\mathrm{CdX}_{2}(\mathrm{HX})_{2}+2 \mathrm{H}^{+}{ }_{\text {aq }}$

From this equation, the expression for the extraction equilibrium constant, $\mathrm{K}_{\text {eq, } \mathrm{E}}$, can be written as,

$\mathrm{K}_{\mathrm{eq}, \mathrm{E}}=\left\{\left[\mathrm{CdX}_{2}(\mathrm{HX})_{2}\right]_{\mathrm{org}}\left[\mathrm{H}^{+}\right]_{\mathrm{aq}}^{2}\right\} /\left\{\left[\mathrm{Cd}^{2+}\right]_{\mathrm{aq}}\left[(\mathrm{HX})_{2}\right]_{\mathrm{org}}^{2}\right\}(3)$

where the subscript "E" denotes extraction conditions, and all concentrations are those after equilibrium has been attained. Then equation (3) can be arranged as,

$\log \left(\mathrm{D}_{\mathrm{Cd}}\right)=\log \mathrm{K}_{\mathrm{eq}, \mathrm{E}}+2\left(\mathrm{pH}+\log \left[(\mathrm{HX})_{2}\right]\right)$

where $\mathrm{D}_{\mathrm{Cd}}$ represents the metal distribution coefficient, defined as,

$\mathrm{D}_{\mathrm{Cd}}=\left[\mathrm{CdX}_{2}(\mathrm{HX})_{2}\right]_{\text {org }} /\left[\mathrm{Cd}^{2+}\right]_{\mathrm{aq}}$

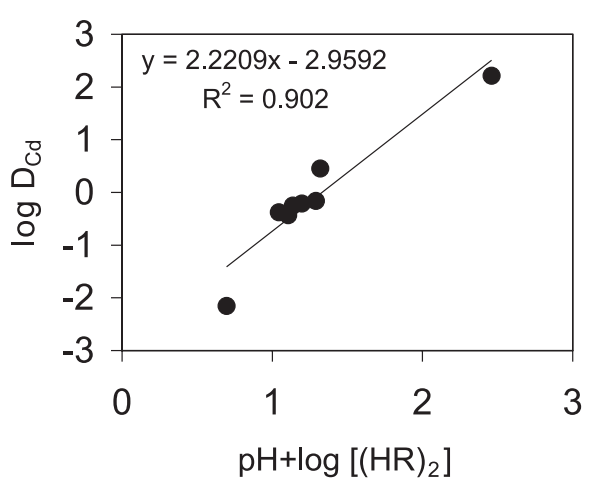

Figure 3. Correlation of extraction experimental results according to equation (4). 
In Figure 3 the experimental results were correlated by equation (4). The slope is nearly equal to 2.0 , indicating that one mole of cadmium would react with two moles of the dimer of the extractant, validating the equilibrium proposed in equation (2). Moreover, from the intersection of the straight line with the ordinate, the extraction equilibrium constant was determined as $\mathrm{K}_{\mathrm{eq}, \mathrm{E}}=4 \times 10^{-3}$ [-]. Although this value seems low, it is possible to achieve a good extraction extent since the $\mathrm{pH}$ of the feed aqueous phase is adjusted around 5.0. The use of the buffer solution allows shifting the reaction towards the formation of the metal-extractant complex. Several authors have reported different values for this equilibrium constant, which have been calculated under different experimental conditions. However, the value of $\mathrm{K}_{\mathrm{eq}, \mathrm{E}}$ obtained in this work is in the order of those calculated by other authors for extraction of cadmium and other metallic ions with this compound using rather similar conditions. For instance, Takeshita et al. ${ }^{33}$ determined in nitrate medium a $5 \times 10^{-3}$ extraction constant using only the phosphoric extractant and a equilibrium constant of 0.2 when TPEN, a hexadentate ligand with nitrogen donors was added to the organic solution.

\section{Cadmium transport measurements}

Stirring conditions in the transfer cell. First it was necessary to find the appropriate stirring speed conditions in the transfer cell used in this study. Complete mixing must not occur between the aqueous feed and the emulsion phases in order to achieve a clear interface between them and allow the interfacial area to be calculated and emulsion breakdown to be reduced. Based on previous experience using this membrane contactor, all experimental runs used a volume ratio of organic solution to metal-acceptor aqueous solution, $\mathrm{V}_{\text {or }} / \mathrm{V}_{\text {aq }}$, of 2.0 to prepare the emulsion phase, and a primary emulsion stirring speed of $1500 \mathrm{rpm}$ during 5 minutes. Furthermore, a stirring speed of $50 \mathrm{rpm}$ was used in the transfer cell, adequate to keep a neat emulsion/feed interface and to overcome the natural resistance in the outer aqueous phase.

The extent of cadmium extraction, $\mathrm{E}_{\text {ext }}[-]$, was determined by measuring the metal concentration in the feed solution as follows:

$\mathrm{E}_{\mathrm{ext}}=\left[\left(\mathrm{C}_{\mathrm{Cdo}}-\mathrm{C}_{\mathrm{Cd}}\right) / \mathrm{C}_{\mathrm{Cd}}\right]$

where $\mathrm{C}_{\mathrm{Cdo}}$ and $\mathrm{C}_{\mathrm{Cd}}$ denote the initial cadmium content in the aqueous acid feed solution and the metal concentration in the raffinate, respectively.
Dependence on extractant concentration. In order to determine the effect of carrier extractant content in the organic phase on cadmium extraction, several experimental runs of metal transport through the organic liquid membrane were carried out, changing the concentration of the carrier in a range between 0.005 to $0.1 \mathrm{~mol} \mathrm{~L}^{-1}$. In all the runs a surfactant concentration of $2 \%\left(\mathrm{w} / \mathrm{w}_{\mathrm{o}}\right)$ and a $2 \mathrm{~mol} \mathrm{\textrm {L } ^ { - 1 }}$ hydrochloric acid concentration in the strip liquor were used. The initial cadmium content in feed solution was $0.001 \mathrm{~mol} \mathrm{~L}^{-1}$ and chloride concentration was $2 \mathrm{~mol} \mathrm{~L}^{-1}$ being the $\mathrm{pH}$ adjusted around a value of 5.0 by using a $0.0125 \mathrm{~mol} \mathrm{~L}^{-1}$ acetic acid-sodium acetate buffer solution. Samples of raffinate were taken at different time intervals. The results are shown in Figure 4.

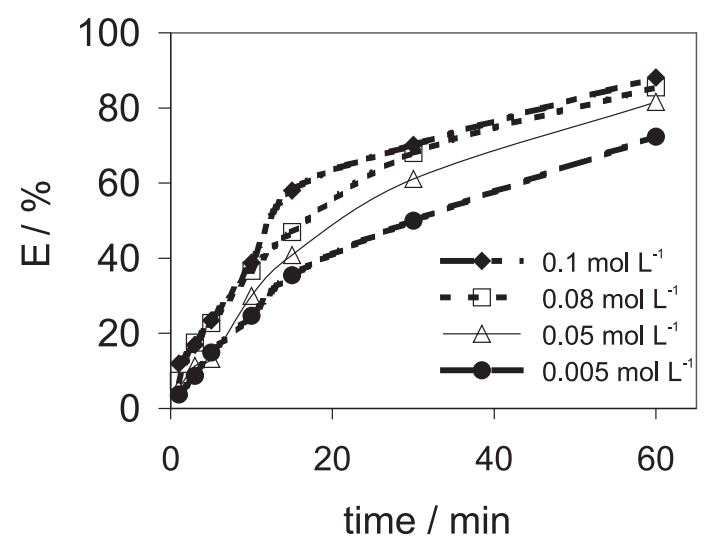

Figure 4. Effect of carrier extractant concentration on the extraction extent of cadmium.

It is seen that the extent of metal transport through the membrane is enhanced as the content of carrier compound in the organic membrane film is increased. It is also seen that metal extraction is favored at the beginning of the experiment. In order to measure this effect the initial extraction rate of metal in each experiment, $\mathrm{R}_{\mathrm{o}}$, was calculated using the following equation:

$\mathrm{R}_{\mathrm{o}}=\mathrm{C}_{\mathrm{Mo}}\left(\mathrm{V}_{\mathrm{aq}} / \mathrm{A}\right)(\mathrm{dE} / \mathrm{dt})$

where $\mathrm{V}_{\text {aq }}$ and $\mathrm{A}$ denote the volume of feed solution and the area of the interface, respectively, $(\mathrm{dE} / \mathrm{dt})$ represents the change in the extent of metal extraction with time, and $\mathrm{R}_{\mathrm{o}}$ is expressed in [mol cm $\mathrm{cm}^{-2} \mathrm{~s}^{-1}$. Figure 5 shows the influence of extractant content in the organic phase on the extent of extraction and on the initial extraction rate. In these experiments the feed aqueous solution composition was same as indicated in Figure 4: $0.001 \mathrm{~mol} \mathrm{~L}^{-1}$ [Cd], $2 \mathrm{~mol} \mathrm{~L}^{-1}\left[\mathrm{Cl}^{-}\right]$and a $\mathrm{pH}$ of 5.0 adjusted using the buffer solution.

It is clear that the chemical reaction plays an important role in metal permeation through the liquid 
membrane. Metal transport through it is a process of mass transfer affected by the equilibrium and kinetics of the extraction chemical reaction between the metallic ion and the carrier. The content of carrier extractant in the organic phase would then affect the chemical extraction reaction at the interface as well as the diffusion process through the membrane. Figure 5 shows that the extraction extent of cadmium from the external aqueous solution increases slighty with D2EHPA content in the range studied, with the influence of this variable somewhat higher on the initial extraction rate, showing clearly that the extraction chemical reaction takes place around the external interface of the organic droplet. An excess of extractant did not change dramatically the extent and the rate of metal extraction. Although D2EHPA has a strong affinity for the metal, the required carrier amount is fixed by the stoichiometry of the cadmium-carrier complexes formed. Besides, an excessive increase in carrier concentration may destabilize the emulsion because of its surface properties and it may also affect the diffusion of chemical species through the membrane due to the increased viscosity of the organic film.

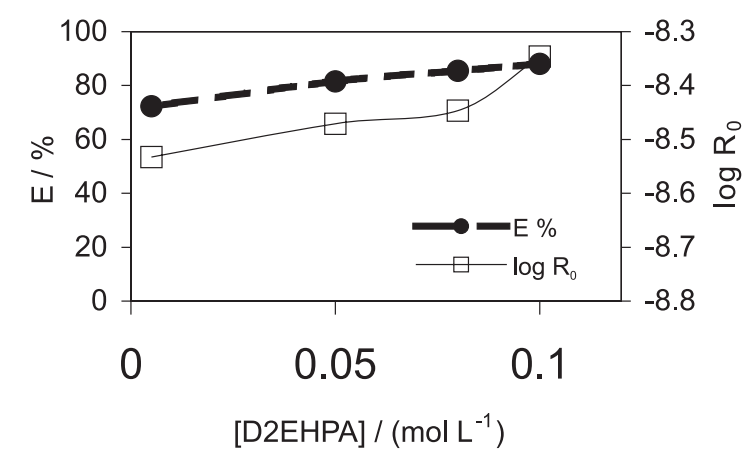

Figure 5. Influence of extractant content at the membrane on extraction extent and on initial extraction rate.

\section{Effect of changing the $\mathrm{HCl}$ content of the receiving phase.} As the extraction step occurs on the external interface of the emulsion droplet, metal transport is necessarily complemented by the simultaneous stripping step at the internal interface of the emulsion globule. At this stage the carrier is regenerated for a new extraction cycle and the metal is stripped and enriched in the strip liquor. In this sense, the extraction of Cd(II) could be influenced by the hydrochloric acid concentration in the stripping phase.

Figure 6 presents the dependence of the extraction extent and the initial metal extraction rate with the change in $\mathrm{HCl}$ content in the stripping solution. In these experimental runs the feed solution was conformed by an aqueous phase whose $\mathrm{pH}$ was 5.0 having a $0.001 \mathrm{~mol} \mathrm{~L}^{-1}$

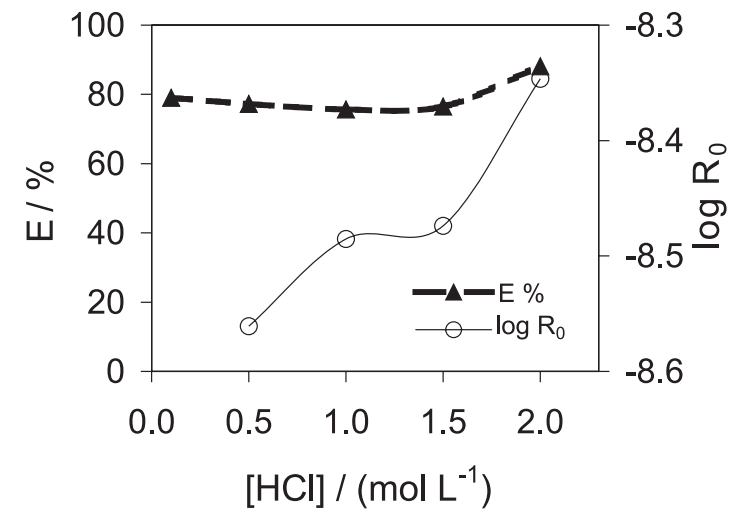

Figure 6. Effect of hydrochloric acid content in the stripping solution on extraction extent and on initial extraction rate.

metal content and a $0.0125 \mathrm{~mol} \mathrm{~L}^{-1}$ chloride concentration. The carrier content at organic liquid membrane was 0.1 mol L $\mathrm{L}^{-1}$ in kerosene.

As can be seen, the extraction extent of metal turned out to be independent of the acid in the stripping solution, indicating that the back-extraction step would have a limited influence on the overall efficiency of the process. However, the $\mathrm{HCl}$ content had a more important effect on the initial extraction rate that was seen as a moderate increase in the metal transport rate in the transfer cell as the hydrochloric acid concentration was increased. This is important because a higher extraction rate would allow a greater number of extraction-stripping cycles and would therefore reduce even more the inventory of organic carrier to achieve the same amount of metal uptake. If it is assumed that the extraction of $\mathrm{Cd}^{2+}$ by D2EHPA proceeds by cation-exchange and that to produce the reverse reaction, i.e. the breaking of the metal-extractant complex, a minimum acid content in the stripping liquor is needed, in subsequent experiments a $2 \mathrm{~mol} \mathrm{~L}^{-1} \mathrm{HCl}$ concentration was used in this phase. This amount of stripping agent generates an acidity gradient, the driving-force of the process, between both aqueous phases sufficient to ensure the permeation of cadmium ions toward the stripping liquor.

Influence of the metal concentration of the feed phase. Figure 7 shows the change in the amount of cadmium extracted over time as a variable of metal concentration in the aqueous feed solution. In these experiments the experimental conditions were as follows: organic phase $0.1 \mathrm{~mol} \mathrm{~L}^{-1}$ D2EHPA, stripping solution $2.0 \mathrm{~mol} \mathrm{~L}^{-1} \mathrm{HCl}$ and feed solution whose $\mathrm{pH}$ was 5.0 adjusted with the buffer solution containing a halide concentration around $0.0125 \mathrm{~mol} \mathrm{~L}^{-1}$.

As expected, metal extraction decreased slightly as the cadmium content in the external aqueous feeding phase 
increased, which is coherent with the necessary amount of carrier to transport a larger quantity of metal. Measurement of the effect of metal concentration in the feed solution on the initial extraction rate seems to be more interesting. Figure 8 shows the dependence of initial metal extraction rate with the change in metal content in the external aqueous solution. The composition of three phases used in these experiments was as described for Figure 7.

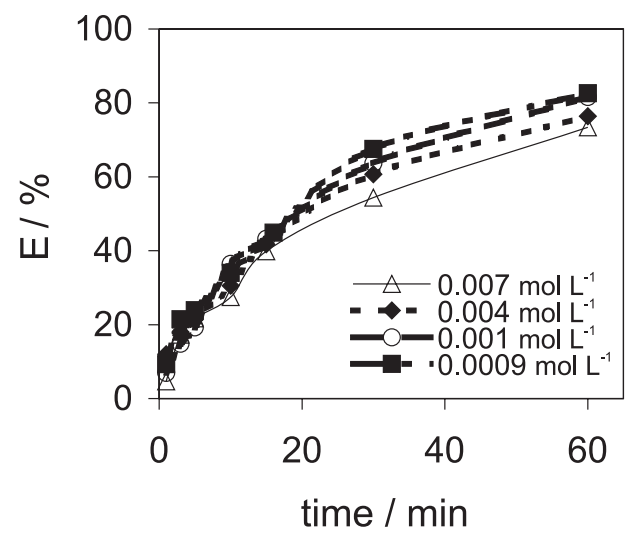

Figure 7. Cadmium extraction extent as a function of feed metal concentration.

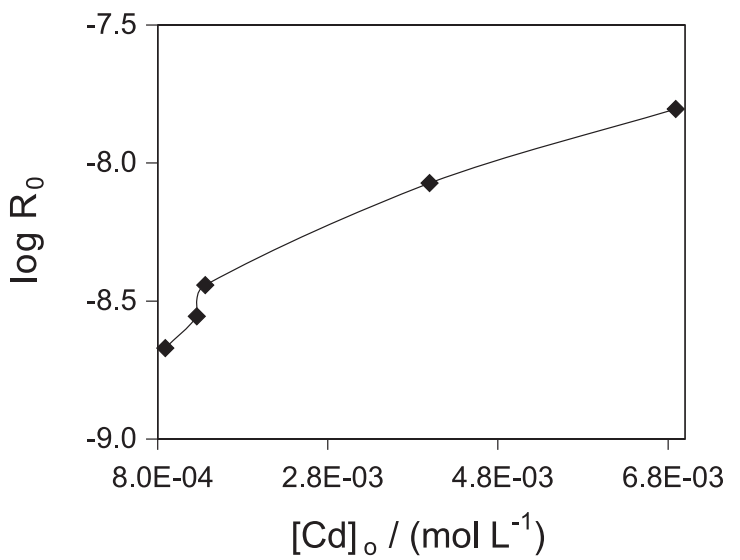

Figure 8. Dependence of initial extraction rate on cadmium concentration in feed aqueous solution.

Under the experimental condition studied there was a clear proportionality between initial rate and metal concentration in the feed solution. The same effect was seen when carrier content was increased in the liquid membrane, confirming the important role of the chemical reaction in the control of the metal permeation process.

Dependence on surfactant concentration. With the purpose of studying the stability of the liquid membrane, different experiments were designed changing the concentration of surfactant, Span-80, in the organic phase. Emulsion liquid membranes are normally unstable, and a certain amount of surfactant must be added in order to avoid emulsion breakdown caused by the coalescence of dispersed drops. Figure 9 shows the effect of surfactant content in the liquid membrane on extraction extent and initial extraction rate. The organic phase was $0.1 \mathrm{~mol} \mathrm{~L}^{-1}$ of carrier and the stripping solution was $2.0 \mathrm{~mol} \mathrm{~L}^{-1} \mathrm{HCl}$. The feed aqueous phase was conformed as follows: a $\mathrm{pH}$ of 5.0 having a $0.001 \mathrm{~mol} \mathrm{~L}^{-1}$ metal content and a 0.0125 mol L ${ }^{-1}$ chloride concentration.

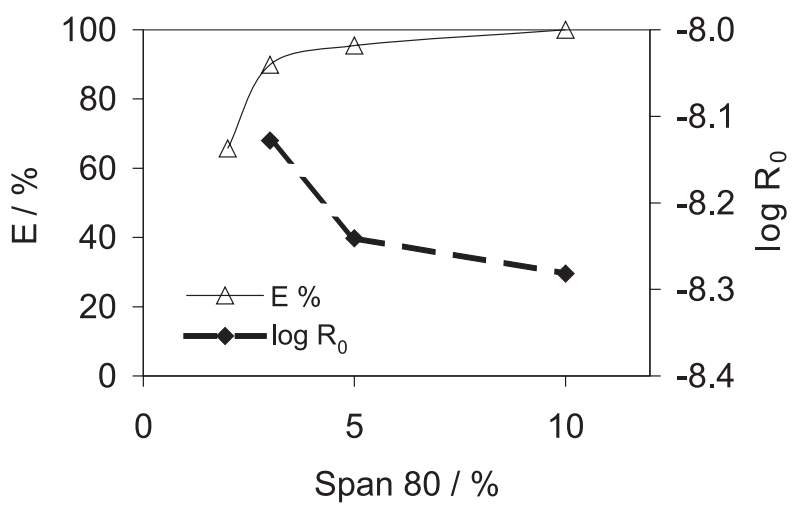

Figure 9. Influence of surfactant content at the membrane on extraction extent and on initial extraction rate.

The surfactant causes a decrease of the system's interfacial tension, contributing to stabilize the emulsion by generating smaller droplets. It is clear from Figure 9 that the extent of cadmium extraction increases as surfactant concentration increases in the organic phase, probably due to the fact that the reduction of the interfacial tension produces suitable conditions for the reaction between the carrier and the metal as their mutual contact is prolonged. This fact also facilitates permeation of the complex through the membrane. However, it is also seen that the use of an unnecessarily high concentration of Span- 80 brought about a decrease of the initial metal extraction rate. It seems that a higher interfacial resistance would be generated as a larger number of surfactant and carrier molecules compete at the interface for the adsorption sites. The primary emulsion was not formed if a surfactant concentration below $1.5 \%\left(\mathrm{w} / \mathrm{w}_{\mathrm{o}}\right)$ was used to prepare the organic solution.

As pointed out previously, ${ }^{22,34}$ metal transport through the membrane would proceeds by a mass transference process accompanied by chemical reaction between the metal and the carrier.

The results shown in this study confirm that the ELM process is a promising alternative to other currently used separation processes, especially for metal recovery from dilute solutions, since it is simpler than conventional solvent extraction (SX) and ion-exchange on solid resins (IX) because the extraction and stripping operations are combined and considerably less solvent is required. 


\section{Conclusions}

Cadmium(II) ions were efficiently extracted by means of an emulsion liquid membrane using a stirred transfer cell-type contactor at $25^{\circ} \mathrm{C}$. The choice of suitable carrier was made based on extraction equilibrium considerations. The liquid membrane was prepared by dissolving D2EHPA (an alkylphosphoric compound) as extractant carrier and Span-80 as surfactant in kerosene. It was found that the extractant carrier concentration in the organic phase had a positive influence on the extent of metal extraction and on initial extraction rate. Increased metal content in the feed metal-donor solution as well as increased stripping agent in the internal aqueous acceptorsolution affected only the initial transport rate. From the experimental results the possible structure of the extracted complex was determined and the apparent extraction equilibrium constant was calculated.

The surfactant concentration used in the study stabilized the emulsion membrane by reducing the interfacial tension. Any unnecessary additional amount of it would occupy the active sorption sites at the interface, competing with the carrier molecules and affecting the efficiency of metal transport.

The experimental results reported here show the ability of the ELM method to be used for the recovery and/or removal of valuable and toxic metals from dilute aqueous solutions. The reduced amount of solvent required for metal extraction and its metal enriching capacity, account for the promising performance of this technology in practical applications.

\section{Acknowledgments}

Financial support of this work by Chile-FONDECYT under Project No. 1040567 and by Argentina/Chile Program SECyT/CONICYT under Project No. 2003-4101 is gratefully acknowledged.

\section{References}

1. Stentrom, S.; Aly, G.; Hydrometallurgy 1985, 14, 231.

2. Loredo, J.; Pereira, A.; Ordóñez, A.; Environ. Int. 2003, 29, 481.

3. Inglezakis, V.; Grigoropoulou, H.; Microporous Mesoporous Mater. 2003, 61, 273.

4. Valenzuela, F.; Andrade, J.; Sapag, J.; Tapia, C.; Basualto, C.; Miner. Eng. 1995, 8, 893.

5. Basualto, C.; Marchese, J.; Valenzuela, F.; Acosta, A.; Talanta 2003, 59, 999.
6. Valenzuela, F.; Vega, M.; Yánez, M.; Basualto, C.; J. Membr. Sci. 2002, 204, 385.

7. Escobar, A.; Schimmel, K.; De Gyves, J.; Rodriguez de San Miguel, E.; J. Chem. Technol. Biotechnol. 2004, 79, 961.

8. Alguacil, F.; Alonso, M.; Hydrometallurgy 2000, 58, 81.

9. Cooney, D.; Jin, C.; Chem. Eng. Commun. 1985, 37, 173.

10. Li, Q.; Liu, Q.; Zhang, Q.; Wei, X. ; Guo, J. ; Talanta 1998, 46, 927.

11. Li, N.; U.S. Pat. 3.779.907, 1973.

12. Kulkarni, P.; Chem. Eng. J. 2003, 92, 209.

13. Alizadeh, N.; Salimi, S.; Jabbari, A.; Sep. Purif. Technol. 2002, 28, 173.

14. Sznejer, G.; Marmur, A.; Colloids Surf., A 1999, 151, 77.

15. Kulkarni, P.; Mukhopadhyay, S.; Bellary, P.; Ghosh, K.; Hydrometallurgy 2002, 64, 49.

16. Matsumoto, M.; Kondo, K.; Nakashio, F.; J. Chem. Eng. Jpn. 1990, 23, 359.

17. Pal, P.; Datta, S.; Bhattacharya, P.; Sep. Purif. Technol. 2002, $27,145$.

18. Lonsdale, H.; J. Membr. Sci. 1982, 10, 81.

19. Hatton, T.; Wardius, D.; AIChE J. 1984, 30, 934.

20. Wright, J.; Nilsen, D.; Hundley, G.; Galvan, G.; Miner. Eng. 1995, 8, 549.

21. Valenzuela, F.; Fonseca, C.; Basualto, C.; Correa, O.; Tapia, C.; Sapag, J.; Miner. Eng. 2005, 18, 33.

22. Valenzuela, F.; Cabrera, J.; Basualto, C.; Sapag-Hagar, J.; Miner. Eng. 2005, 18, 1224.

23. Dingsheng, H.; Ming, M.; Hydrometallurgy 2000, 56, 157.

24. Sato, T.; Nakamura, T.; Fujimatsu, T.; Bull. Chem. Soc. Jpn. 1981, 54, 2656.

25. Raghuraman, J.; Tirmizi, P.; Environ. Sci. Technol. 1995, 29, 979.

26. Casas, I.; Miralles, N.; Sastre, A.; Aguilar, M.; Polyhedron 1986, $5,2039$.

27. Stentrom, S.; Aly, G.; Hydrometallurgy 1985, 14, 257.

28. Alguacil, F.; Navarro, P.; Hydrometallurgy 2001, 61, 137.

29. Alguacil, F.; Martínez, S.; J. Membr. Sci. 2000, 176, 249.

30. Vandegrift, G.; Horwitz, E.; J. Inorg. Nucl. Chem. 1979, 42, 119.

31. Sato, Y.; Valenzuela, F.; Tsuneyuki, T.; Kondo, K.; Nakashio, F.; J. Chem. Eng. Jpn. 1987, 20, 317.

32. Valenzuela, F.; Auspont, J.; Basualto, C.; Tapia, C.; Sapag, J.; Chem. Eng. Res. Des. 2005, 83, 247.

33. Takeshita, K.; Watanabe, K.; Nakano, Y.; Watanabe, M.; Hydrometallurgy 2003, 70, 63.

34. Marchese, J.; Valenzuela, F.; Basualto, C.; Acosta, A.; Hydrometallurgy 2004, 72, 309.

Received: April 20, 2006 Published on the web: September 26, 2006 